\title{
Distribution of Trace Elements, Rare Earth Elements and Ecotoxicity in Sediments of the Kosva Bay, Perm Region (Russia)
}

\author{
Evgeniya Ushakova ${ }^{1 *}$, Elena Menshikova', Sergey Blinov', \\ Sergey Vaganov ${ }^{1}$, Roman Perevoshchikov ${ }^{1}$ \\ 1 Natural Science Institute, Perm State University, Genkel St. 4, 614990 Perm, Russia \\ * Corresponding author's e-mail: ushakova.evgeniya@gmail.com
}

\begin{abstract}
Over a long period of time, a huge amount of technogenic bottom sediments has been accumulating in the Kosva Bay with significant concentrations of amorphous iron and aluminium hydroxides, which, in turn, are active sorbents of pollutants. This study examines the distribution of trace elements and rare earth elements and their toxicity in the Kosva Bay of the Kama Reservoir (Perm Region, Russia). In the middle reach, the Kosva River crosses the Kizel coal basin, where acid mine water is discharged from closed mines. The average content of trace elements in the samples of bottom sediments of the bay varies from $0.10 \mathrm{mg} / \mathrm{kg}(\mathrm{Se})$ to $176.36 \mathrm{mg} / \mathrm{kg}(\mathrm{Ba})$. The amount of rare earth elements varies from 66.8 to $83.6 \mathrm{mg} / \mathrm{kg}$. The ecological significance of trace elements and rare earth elements was studied using an element-by-element assessment (EF and Igeo), Potential Ecological Risk Index (RI), Mean Probable Effect Concentration Quotient (PECQ), and two bioassays (Daphnia magna Straus and Scenedesmus quadricauda (Turp.) Breb. The highest $\mathrm{Hg}$ enrichment was found at two sampling points. Taking into account the average value of Igeo, the pollution by $\mathrm{Co}, \mathrm{V}, \mathrm{Nb}, \mathrm{Hg}, \mathrm{Sn}, \mathrm{Zn}, \mathrm{Sm}, \mathrm{Ni}, \mathrm{Cr}$, and $\mathrm{Gd}$ is the highest and corresponds to extremely contaminated category. The RI values indicate that pollution categories vary from moderate risk to considerable risk. According to mean PECQ values, bottom sediments of the bay have moderate potential toxicity towards biological communities. Results of chronic and acute toxicity on test objects $D$. magna and Scenedesmus quadricauda Breb show the water extract from bottom sediments having no effects on the test objects. The results of the study show that in order to assess the quality of bottom sediments, an integrated approach, combining chemical and ecotoxicological analyses, is needed.
\end{abstract}

Keywords: trace elements, rare earth elements, sedimentation, bottom sediment, ecotoxicity, acid mine drainage.

\section{INTRODUCTION}

The mining industry is considered a significant anthropogenic source of water and sediments pollution due to acid mine drainage (AMD) from mine tailings, specifically those of abandoned mines, posing serious environmental hazard to aquatic life [Martinez-Lopez et al., 2021; Alvarenga et al., 2021]. Elevated trace elements concentrations are often found in areas where acid mine waters are discharged from abandoned metal-bearing mines [Wang et al., 2021; Wright et al., 2018]. Trace elements and rare earth elements pollution in the river environment can also have adverse effects on organisms and humans, enter the food chain, and accumulate in aquatic organisms, sometimes at harmful levels [Chan et al., 2021; Byrne et al., 2013; Adeel et al., 2019]. In places where acid mine waters are discharged, low $\mathrm{pH}$, high concentrations of sulphates, $\mathrm{Fe}, \mathrm{Al}$, $\mathrm{Mn}, \mathrm{Cu}, \mathrm{Ni}, \mathrm{Zn}, \mathrm{Cd}, \mathrm{Co}, \mathrm{Pb}$ and other trace elements that are common to specific deposits are generally found as a result of redox processes [Younger, 2001; Galhardi and Bonoto, 2016; Silva et al., 2013]. The behaviour of rare earth elements under these conditions is similar to other metals, since it also depends on the $\mathrm{pH}$ of the medium. For example, the results of studies within Darrehzar porphyry copper mine show that the distribution of light rare earth elements on suspended particles is less than that of middle rare earth elements and heavy rare earth elements, which confirms similar 
results of researchers [Soltani et al., 2014]. At the same time, the studies note a significant transfer of many elements over considerable distances from the source, for example, into the Huelva estuary by the Tinto and Odiel Rivers due to long-term mining activities in the Iberian Pyrite Belt, where $7900 \mathrm{t}$ of Fe, $5800 \mathrm{t}$ of Al, $3500 \mathrm{t}$ of $\mathrm{Zn}, 1700 \mathrm{t}$ of $\mathrm{Cu}$, and $1600 \mathrm{t}$ of $\mathrm{Mn}$ are removed annually [Torre et al., 2019; Nieto et al., 2007]. The closed mines of the Kizel coal basin, located in the eastern part of Perm Region (Russia), negatively affect the Kama River basin in the upper part of the drainage basin [Fetisova, 2021; Pyankov et al., 2021; Krasilnikova and Blinov, 2017; Menshikova et al., 2020]. The AMD into the Kosva, Yaiva and Chusovaya Rivers and subsequent migration of the matter downstream of these rivers ensure the influx of about 21,455 tonnes of iron, 1128 tonnes of aluminium, and 217 tonnes of manganese per year into the water area of the Kama Reservoir [Report, 2020]. Numerous studies show that the presence of $\mathrm{Fe}, \mathrm{Al}$ and $\mathrm{Mn}$ hydroxides in bottom sediments enhance sorption for a number of trace elements, which affects chemical composition of both bottom sediments and water [Mohammad Ali et al., 2015; Zhang et al., 2014]. At the same time, trace elements and rare earth elements input into the environment is increasing globally every year [Worakhunpiset, 2018]. Bottom sediments in a river mouth, generally, accumulate a large number of pollutants that come from urban, industrial, and agricultural waste water and acid mine water and further enter water bodies. At the same time, TE and rare earth elements pollution of bottom sediments predetermines the formation of benthic species' habitat and early life stages of pelagic species, and can affect food chains [Baran et al., 2016]. Some concentrations of trace elements and rare earth elements in bottom sediments can be toxic to the aquatic ecosystem [Muneer et al., 2022; Chan et al., 2021]. Toxicity assessment of bottom sediments containing high concentrations of trace elements is an integral part of the modern environmental assessment of water quality in water bodies. Currently, the most common method for such assessment is the use of Daphnia magna Straus, 1820 and the green protococcal algae Scenedesmus quadricauda (Turp.) Breb, which has been confirmed by a number of studies aimed at determining potential toxicity of bottom sediments and bioavailability of trace elements and rare earth elements [Lee et al., 2015; Gorgulenko and Yanygina, 2014; Terra et al., 2010; Opekunov et al., 2020]. Various integral methods are also used to summarize the contamination of bottom sediments: geoaccumulation index (Igeo), sediment enrichment factor (SEF), potential ecological risk index (RI), sediment quality guidelines (SQGs), pollution load index (PLI), sediment pollution index (SPI), etc. [Skorbiłowicz et.al., 2018; Sojka et.al., 2019; Lin et. Al., 2013; Kulbat and Sokolowska, 2019].

The research objectives are (i) to study the concentrations and spatial distribution of trace elements and rare earth elements in bottom sediments of the Kosva Bay of the Kama Reservoir, (ii) and to evaluate the ecotoxicity of bottom sediments to ensure reasonable environmental risk assessment.

\section{MATERIALS AND METHODS}

\section{Field sampling and chemical analysis}

The Kosva Bay is one of the largest bays in the water area of the Kama Reservoir. It is located in Perm Region (Russia) between $58^{\circ} 52^{\prime}$ and $58^{\circ} 56^{\prime}$ north latitude and $56^{\circ} 19^{\prime}$ and $56^{\circ} 40^{\prime}$ east longitude. The waters of the Kosva River enter the Kosva Bay. The Kosva River is $261 \mathrm{~km}$ long, and the drainage basin area is $6570 \mathrm{~km}^{2}$. The Kosva River is located in the backwater of the Kama Reservoir, which was formed after the construction of the Kama Hydroelectric Power Station located downstream at a distance of about 115 $\mathrm{km}$. The bay is actively used by the local population for recreational purposes (rafting, fishing). The upper part of the Kosva River basin drains the mountain ranges of the Middle Urals. In the middle part of the drainage basin, the river goes across the Kizel coal basin, where, after mine closures, acid mine waters are discharged. The lower part of the drainage basin is a flat area. The bay sediments are formed by finely dispersed alluvial sediments with a thickness of $0.42 \mathrm{~m}$ to $1.42 \mathrm{~m}$, which lie on the bedrock of the Permian system and gravel sediments.

Bottom sediment samples of the Kosva Bay were collected from ice during winter base flow period in 2021 using patented sampler (RU 2762631C1, registration date 21.12.2021). Core samples were collected at the old stream bed of the Kosva River, where finely dispersed fraction deposition occurs the most (Figure 1, Table 1). Four core samples were collected 
Table 1. Sampling points location in the Kosva Bay

\begin{tabular}{|c|c|c|c|}
\hline Sampling point & Latitude $(\mathrm{N})$ & Longitude $(\mathrm{E})$ & Distance from the mouth, $\mathrm{km}$ \\
\hline B1 & $58^{\circ} 52^{\prime} 38.00^{\prime \prime}$ & $56^{\circ} 38^{\prime} 14.59^{\prime \prime}$ & 0 \\
\hline B2 & $58^{\circ} 53^{\prime} 43.22^{\prime \prime}$ & $56^{\circ} 36^{\prime} 30.86^{\prime \prime}$ & 1.2 \\
\hline B3 & $58^{\circ} 53^{\prime} 16.98^{\prime \prime}$ & $56^{\circ} 32^{\prime} 43.08^{\prime \prime}$ & 4.8 \\
\hline B4 & $58^{\circ} 52^{\prime} 30.48^{\prime \prime}$ & $56^{\circ} 26^{\prime} 17.07^{\prime \prime}$ & 11.2 \\
\hline
\end{tabular}

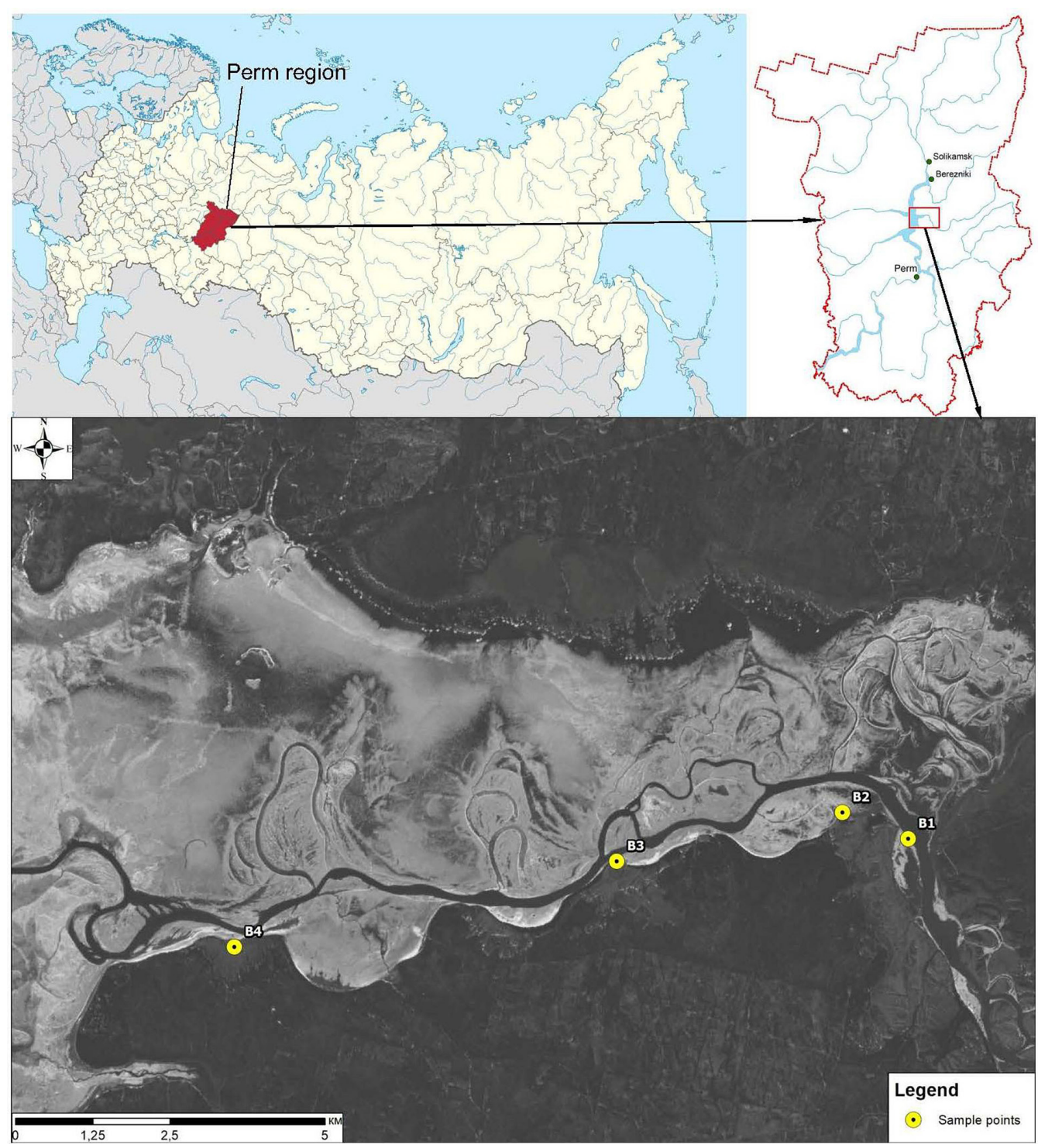

Figure 1. Location map of the Kosva Bay in Perm Region (Russia)

with core sampler reaching all the way down the fine-dispersed fraction to gravel deposits or bedrocks. In this study, core samples were analysed in the upper $0.20 \mathrm{~m}$ layer.

The collected core samples of bottom sediments with intact structure were divided into separate samples taking into account their lithology. Then they were packed, transported and stored at $4^{\circ} \mathrm{C}$ until the analyses. In the laboratory, the samples were air dried at room temperature, then ground with a mortar and pestle and sieved through a $2 \mathrm{~mm}$ sieve.

The sediment samples were analyzed to determine mineralogical composition, major oxides, trace element and rare earth element concentrations, and grain size fractions. The mineralogical composition of the sediments was determined by X-ray diffraction (XRD) using diffractometer D2 Phaser (Bruker). Samples ( $2 \mathrm{~g}$ ) were ground into powder with a particle size of less than $44 \mu \mathrm{m}$ using ball mill 
Pulverisette 5 (Bruker). Recording settings: divergence slit - $0.6 \mathrm{~mm}$; Soller slit - primary $2.5^{\circ}$, secondary $2.5^{\circ}$; angular range - from 5 to $70^{\circ} 2 \theta$; impulse speed at each point $-1.0 \mathrm{~s}$; step size $-0.03^{\circ}$. X-ray diffraction analysis (using D2 Phaser, Bruker, Billerica, MA, USA) was carried out to determine basic oxides. Loss on ignition (LOI) was determined by weight loss upon heating $1 \mathrm{~g}$ of the separated sample at $950^{\circ} \mathrm{C}$ for 90 minutes. Analysed and measured concentrations of elements were in accordance, taking into account their analytical errors $( \pm 10 \%)$. Total element concentration of trace elements $(\mathrm{Li}, \mathrm{Sc}$, $\mathrm{V}, \mathrm{Cr}, \mathrm{Co}, \mathrm{Ni}, \mathrm{Cu}, \mathrm{Zn}, \mathrm{As}, \mathrm{Se}, \mathrm{Rb}, \mathrm{Sr}, \mathrm{Nb}, \mathrm{Mo}, \mathrm{Cd}$, $\mathrm{Sn}, \mathrm{Sb}, \mathrm{Hg}, \mathrm{Pb}, \mathrm{Th}, \mathrm{U})$ and rare earth elements ( $\mathrm{La}$, $\mathrm{Ce}, \mathrm{Pr}, \mathrm{Nd}, \mathrm{Sm}, \mathrm{Eu}, \mathrm{Gd}, \mathrm{Tb}, \mathrm{Dy}, \mathrm{Ho}, \mathrm{Er}, \mathrm{Tm}, \mathrm{Yb}, \mathrm{Lu})$ in the sediments was assessed after digestion in a mixture of $\mathrm{HNO}_{3}$ acids or other acids (such as $\mathrm{HCl}$, $\mathrm{HClO}_{4}$ and $\mathrm{H}_{2} \mathrm{SO}_{4}$ ) diluted with deionized water. Element concentrations were analysed using Bruker Aurora M90 (ICP-MS). High purity acids were used. Along with the analysed samples, digestion of control samples (blank samples) and one standard sample was carried out. The accuracy of analytical procedures for determining total concentration of metals was checked using standard samples from the Institute of Geochemistry Siberian Branch of the Russian Academy of Sciences (Irkutsk, Russia). Depending on the concentration of chemical elements, typical measurement errors were in the following ranges: $<0.001 \mathrm{mg} / \mathrm{kg}-\mathrm{RSD} 15 \mathrm{v} 10 \%$; 0.001-0.1 $\mathrm{mg} / \mathrm{kg}$ - RSD 10-5\%; 0.1-1 mg/kg - RSD 5-3\%; $>1 \mathrm{mg} / \mathrm{kg}-\mathrm{RSD} 3 \%$.

\section{Sediments contamination index}

Bottom sediments pollution with trace elements and rare earth elements was assessed using two widely applied indices: enrichment factor (EF) and geoaccumulation index (Igeo) [Sakan et al., 2009; Müller, 1969]. Al, Fe, Mn, Ca and $\mathrm{Mg}$ are typically used as pillars for calculating EF [Iqbal and Shah, 2015]. In this study, EFs were computed using $\mathrm{Mn}$ as a reference metal. To calculate EF and Igeo indices, values of the upper continental crust were used as background values [Rudnick and Gao, 2003]. To assess the effect of multi-element pollution in sediments, potential ecological risk index (RI) of Hakanson [1980] was calculated. A sample taken in the middle reach of the Kosva River was used as background concentrations of trace elements and rare earth elements before the siting of enterprises and discharge of acid mine waters. Where Ti is the toxicresponse factor for a given substance for trace elements $(\mathrm{Hg}=\mathrm{U}=40, \mathrm{Cd}=30, \mathrm{Sb}=13, \mathrm{As}=10$, $\mathrm{Sr}=6, \mathrm{~Pb}=\mathrm{Cu}=\mathrm{Ni}=5, \mathrm{Cr}=2, \mathrm{Zn}=\mathrm{Ba}=\mathrm{Co}=$

Table 2. The criteria of contamination level in bottom sediments

\begin{tabular}{|c|c|c|}
\hline Assessment indices & Values & Category of contamination level \\
\hline \multirow{5}{*}{$\begin{array}{l}\text { Enrichment Factor (EF) } \\
E F=\frac{\left(C_{x} / C_{\text {ref }}\right) \text { sediment }}{\left(C_{x} / C_{\text {ref }}\right) \text { background }} \\
C_{x} \text { and } C_{\text {ref }} \text { are the sediment sample concentrations } \\
\text { of the heavy metal and refers to concentration of } \\
\text { reference element for normalization. }\end{array}$} & $\mathrm{EF} \leq 2$ & Deficiency to minimal enrichment \\
\hline & $2<\mathrm{EF} \leq 5$ & Moderate enrichment \\
\hline & $5<\mathrm{EF} \leq 20$ & Significant enrichment \\
\hline & $20<\mathrm{EF} \leq 40$ & Very high enrichment \\
\hline & $\mathrm{EF}>40$ & Extremely high enrichment \\
\hline Geoaccumulation index (Igeo) & Igeo $\leq 0$ & Practically uncontaminated \\
\hline \multirow{6}{*}{$\begin{array}{l}l_{\text {geo }}=\log _{2}\left(\frac{C_{n}}{1.5 B_{n}}\right) \\
C n \text { is the content of element considered in sediment } \\
\text { and } B n \text { is the geochemical background concentration } \\
\text { from preindustrial area or continental earth crust. }\end{array}$} & $0<\operatorname{lgeo} \leq 1$ & Uncontaminated to moderately contaminated \\
\hline & $1<\operatorname{lgeo} \leq 2$ & Moderately contaminated \\
\hline & $2<$ lgeo $\leq 3$ & Moderately to Heavily contaminated \\
\hline & $3<\operatorname{lgeo} \leq 4$ & Heavily contaminated \\
\hline & $4<\operatorname{lgeo} \leq 5$ & Heavily to Extremely contaminated \\
\hline & $\operatorname{lgeo}>5$ & Extremely contaminated \\
\hline Potential ecological risk index (RI) & \multirow{2}{*}{$\mathrm{RI}<150$} & \multirow{2}{*}{ Low risk } \\
\hline \multirow{4}{*}{$\begin{array}{l}R I=\sum_{i=1}^{n} E_{r}^{i}=\sum_{i=1}^{n}\left(T_{r}^{i} \times C_{s}^{i} / C_{B}^{i}\right) \\
\text { Where } C_{S}^{i} \text { is the measured concentration of } \\
\text { sedimentary TE and REE; } C_{B}^{i} \text { is the background } \\
\text { preindustrial level of sedimentary TE and REE; } \mathrm{T}_{r}^{i} \text { is } \\
\text { the toxic response factor for the given elements of " } \mathrm{i} \text { "; } \\
\mathrm{E}_{r}^{i} \text { is the potential ecological risk index. }\end{array}$} & & \\
\hline & $150<\mathrm{RI}<300$ & Moderate risk \\
\hline & $300<\mathrm{RI}<600$ & Considerable risk \\
\hline & $\mathrm{RI}>600$ & High risk \\
\hline
\end{tabular}


$1, \mathrm{Li}=\mathrm{V}=0)$ and $\operatorname{REE}(\mathrm{Lu}=20, \mathrm{Eu}=\mathrm{Tb}=\mathrm{Ho}$ $=\mathrm{Tm}=10, \operatorname{Pr}=\mathrm{Sm}=\mathrm{Gd}=\mathrm{Dy}=\mathrm{Er}=\mathrm{Yb}=5$, $\mathrm{Nd}=2, \mathrm{La}=\mathrm{Ce}=1$ ) [Chen, 2021 Yi et al., 2020; Nkansah et al., 2017]. The level of trace element and rare earth element pollution in bottom sediments of the Kosva Bay was calculated using the equations given in Table 2.

The probable effect concentration (PEC) and the mean PEC quotient (PECQ) were used as additional tools for assessing contamination to determine the hazard level of trace elements in sediments according to Sediment Quality Guidelines (SQG) [Macdonald et al., 2000]. Sediments that posed a threat to aquatic organisms were classified as toxic if pollutant concentrations were higher than the probable effect concentration (PEC) (mg/kg): $\mathrm{Zn}-459$, $\mathrm{Cu}-150, \mathrm{~Pb}-128, \mathrm{Cd}-4.98, \mathrm{Ni}-48.6, \mathrm{Cr}$ - 111, Hg - 1.1, As - 33. The mean PECQ was calculated as the average ratio of each element concentration to its corresponding PEC (PECQ $=\sum(\mathrm{c} / \mathrm{PEC}) / \mathrm{n}, \mathrm{c}-$ concentration resents of trace elements in the sediments, PEC - probable effect concentration, and $\mathrm{n}$ - number of elements) [Boguta et al., 2022]. To assess potential harmful effects based on the mean PECQ in each sample, a toxicity classification system was used: non-adverse effect (PECQ <0.1), slightly adverse effect $(0.1<$ PECQ $<0.5)$, moderate effect $(0.5<$ PECQ $<1.0)$, and heavy effect (PECQ> 1.0) [Szara et al., 2020].

\section{Ecotoxicity test}

Biotesting was carried out in the accredited Centre for Laboratory Analysis and Technical Measurements in the Volga Federal District. When determining the integral toxicity of water samples, we used two test objects of different trophic groups: lower crustaceans Daphnia magna Straus, 1820 and green protococcale algae Scenedesmus quadricauda (Turp.) Breb. [Federal Register FR 1.39.2007.03222 2007; Federal Register FR 1.39.2007.03223 2007]. Chronic toxicity of bottom sediments was identified by the mortality rate and growth inhibition of newborn crustaceans D. magna after 24 days. The cultivation of individuals and further experiments were carried out at $20 \pm 2{ }^{\circ} \mathrm{C}$ and at $500-1000 \mathrm{~lx}$. The experiment had been carried out in three parallel series without dilution for 24 days. Ten newborn crustaceans, aged 6-24 hours, were placed in the test environment. We used cultivation water as control, in which the entire culture lives in the laboratory. Death of $50 \%$ D. magna individuals within 24 days served as the indicator of chronic toxicity of the studied bottom sediments. The green protococcal algae Scenedesmus quadricau$d a$ Breb. was used to determine acute toxicity in the growth phase within 3-5 days after reseeding. In two parallel series of dilutions $(100 \%, 50 \%$, $25 \%, 10 \%, 5 \%$ and $1 \%$ ), the acute toxic effect of the aqueous extract had been determined for 72 hours by changing (decreasing) number of algal cells. The number of cells was counted in the Goryaev chamber under a light microscope. The relative change (in \%) in the number of algal cells for each dilution in comparison with control (I) was calculated using the formula (1).

$$
I=\left(X_{k}-X_{S}\right) / X_{k} \times 100 \%
$$

where: $X_{k}$ is the average value of the test parameter in the control; $X_{S}$ is the average value of the test parameter in the experiment; $I$ is the change in the number of algal cells. At $I<20 \%$, a test sample has no acute toxic effect. At $I>50 \%$, a test sample has an acute toxic effect.

The toxicity classification system PE (Percent toxic effect) developed by Persoone et al. [2003] was used to assess the toxicity of each bioassay: class I - no acute toxicity PE $<20 \%$; class II slight acute toxicity $20 \%<\mathrm{PE}<50 \%$; class III toxic $50 \%<\mathrm{PE}<100 \%$; class IV - very high acute toxicity, $\mathrm{PE}=100 \%$.

\section{RESULTS AND DISCUSSION}

In the water area of the Kosva Bay, there are factors that contribute to the highest accumulation of trace elements in bottom sediments. All sediments in the bay are characterized by uniform distribution of the silt $>$ clay $>$ sand particle size. An increase in the sorption properties of bottom sediments is conditioned by the significant content of a fraction of less than $0.05 \mathrm{~mm}$ in them with the predominance of particles with a size of $1.25-50 \mu \mathrm{m}$. According to numerous studies, namely the fine-grained bottom sediments, due to their large surface area, accumulate inorganic and organic components in aquatic systems [Daulvater, 2000; Opekunov et al., 2021]. Clay minerals, plagioclase, and K-feldspar, in addition to quartz, predominate in the mineral composition of bottom sediments of the bay. 


\section{Major elements}

The content of main elements (in the form of oxides) in the Kosva Bay sediments is shown in Figure 2.

The composition of the bay sediments had a significant content of $\mathrm{SiO}_{2}$ (49.6 and 64.1 wt.\%) with an average value of $54.4 \mathrm{wt} . \%$. The content of aluminium oxide $\left(\mathrm{Al}_{2} \mathrm{O}_{3}\right)$ was the highest among the identified metal oxides, with a range of 10.316.5 wt.\%, with an average value of 13.3 wt.\%. Iron oxide $\left(\mathrm{Fe}_{2} \mathrm{O}_{3}\right)$ with a range of 8.0-10.4 wt.\%, with an average value of $9.4 \mathrm{wt} . \%$, was identified as the second most common metal oxide. The predominance of basic oxides of silica, iron, and aluminium was in agreement with their mineral composition. The content of $\mathrm{K}_{2} \mathrm{O}$ and $\mathrm{MgO}$ varied between 1.1 and $1.8 \mathrm{wt} . \%$ in the studied samples. The contents of other oxides including $\mathrm{Na}_{2} \mathrm{O}$,
$\mathrm{CaO}, \mathrm{P}_{2} \mathrm{O}_{5}, \mathrm{TiO}_{2}$ and $\mathrm{SO}_{3}$ were significantly lower compared to the measured $\mathrm{SiO}_{2}, \mathrm{Al}_{2} \mathrm{O}_{3}$ and $\mathrm{Fe}_{2} \mathrm{O}_{3}$. LOI values were relatively consistent for all samples, varying between $12.2-21.4$, with an average value of 16.9 wt. $\%$.

The major oxides were normalized to UCC values. They are shown in Figure 3.

The highest values relative to the UCC values were found for the $\mathrm{P}_{2} \mathrm{O}_{5}$ content. A number of researchers note that recently, $\mathrm{P}_{2} \mathrm{O}_{5}$ has been used as an indirect indicator of anthropogenic impact [Kublitskiy et al., 2020]. At the same time, high concentrations of $\mathrm{P}_{2} \mathrm{O}_{5}$ correlate with an increase in organic matter in the runoff going into the basin, an increase in bioproduction - with an increase in sedimentation, which is confirmed by high LOI values. This was shown specifically by studies in Spain, where the LOI was $17-31$ wt.\% in fluvial estuary of the Tinto River [Gala'n et al., 2003].

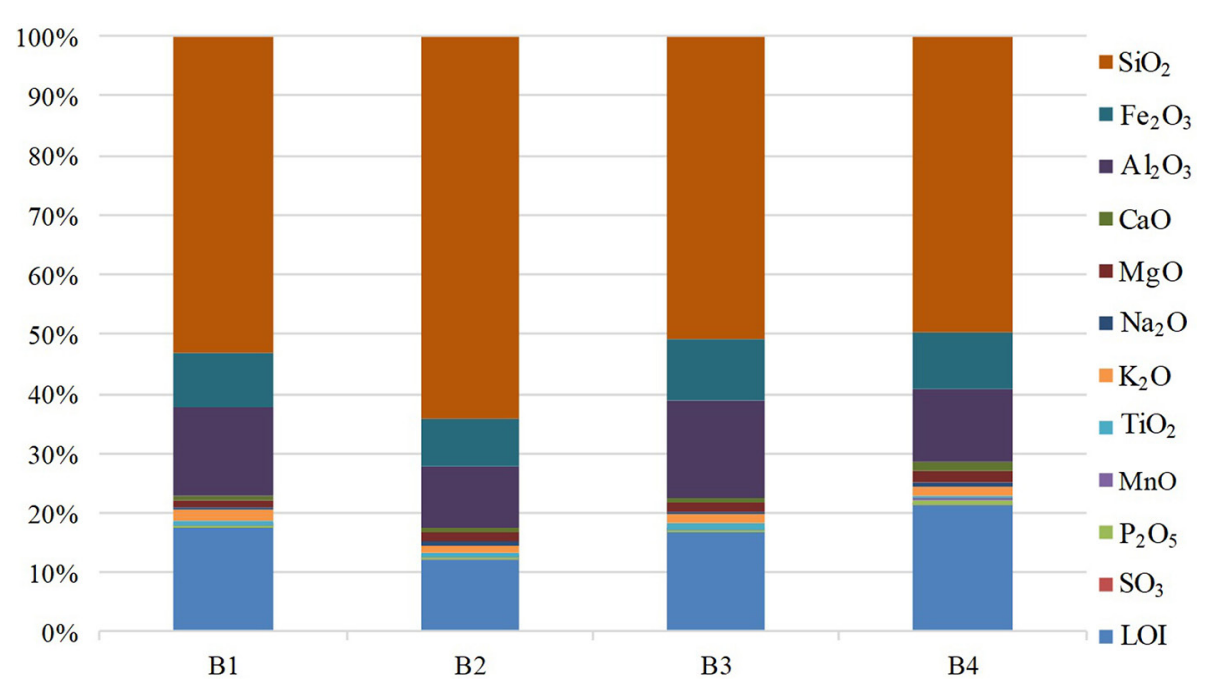

Figure 2. Distribution of major oxides in bottom sediments

\section{Sample/UCC}

10

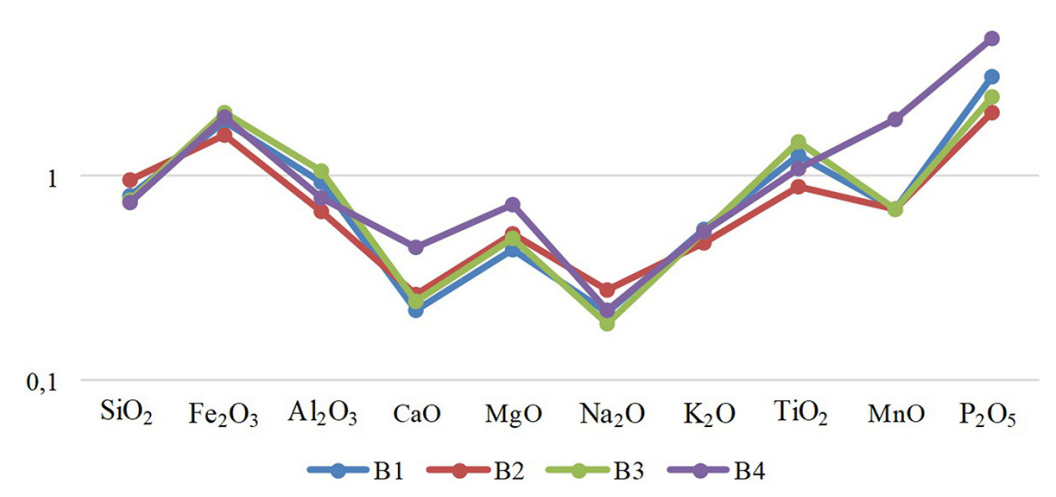

Figure 3. Multi-element plot showing river sediment compositions normalized to the UCC values [Rudnick and Gao, 2003] 
In core samples taken from the bottom sediments of the Colorado River delta, LOI ranged from 10 to $20 \%$ [Daesslé et al., 2009]. Some of the trace elements actively bind to organic matter in sediments exposed to AMD, as in the Chonam-ri creek sediments (Korea), where high concentrations of $\mathrm{Cu}$ and $\mathrm{Zn}$ were compared with measured loss-on-ignition (LOI) [Yung et al., 2005].

The content of $\mathrm{SiO}_{2}, \mathrm{Al}_{2} \mathrm{O}_{3}, \mathrm{TiO}_{2}$, and $\mathrm{MnO}$ in bottom sediments of the Kosva Bay was, on average, within the UCC values. At the same time, at sampling point $\mathrm{B} 4$, the $\mathrm{MnO}$ content was significantly higher relative to other sampling points. The oxides $\mathrm{CaO}, \mathrm{Na}_{2} \mathrm{O}, \mathrm{K}_{2} \mathrm{O}$, and $\mathrm{MgO}$ were significantly depleted compared to the UCC values. Deficiencies in the main feldspar components such as $\mathrm{Na}_{2} \mathrm{O}, \mathrm{CaO}$, and $\mathrm{K}_{2} \mathrm{O}$ compared to the UCC values suggest possible loss of feldspars during chemical weathering. In general, the terrigenous and organogenic types of sedimentation prevail in the Kosva Bay.

Iron oxides, clay minerals, and organic material in the Kosva Bay sediments have high absorption capacity and accumulate trace elements, which is confirmed by studies on other water systems [Zhang et al., 2014; Ren et al., 2021]. It was noted in numerous studies that high concentrations of toxic metals in bottom sediments are associated with the amorphous structure of iron, aluminium, and manganese oxides [Balkis et al., 2010; Fonseca et al., 2021].

\section{Trace elements}

Concentrations of trace elements found in sediments of the Kosva Bay are presented in Table 3 together with the concentrations of trace

Table 3. Trace elements content in bottom sediments of the Kosva Bay and river mouths of the world, $(\mathrm{mg} / \mathrm{kg})$

\begin{tabular}{|c|c|c|c|c|c|c|c|c|}
\hline Parameters & \multicolumn{2}{|c|}{ Kosva Bay } & $\begin{array}{c}\text { Sediment } \\
\text { in AMD } \\
\text { zone }\end{array}$ & $\begin{array}{c}\text { Hengshi } \\
\text { River, China }\end{array}$ & $\begin{array}{l}\text { Amarillo } \\
\text { River, } \\
\text { Argentina }\end{array}$ & $\begin{array}{l}\text { Tinto, } \\
\text { Spain }\end{array}$ & $\begin{array}{l}\text { Cai River } \\
\text { estuary, } \\
\text { Vietnam }\end{array}$ & $\begin{array}{c}\text { Shatt Al-Arab } \\
\text { River, Iraq }\end{array}$ \\
\hline $\begin{array}{l}\text { Source } \\
\text { pollution }\end{array}$ & \multicolumn{2}{|c|}{ Coal mine } & & Polymetallic & $\begin{array}{l}\text { High- } \\
\text { sulphidation } \\
\text { epithermal } \\
\text { deposits }\end{array}$ & $\begin{array}{l}\text { Sulphide } \\
\text { deposits }\end{array}$ & $\begin{array}{c}\text { Agrochemicals, } \\
\text { industrial zones } \\
\text { with their ports }\end{array}$ & $\begin{array}{l}\text { Oil industry, } \\
\text { domestic, } \\
\text { agricultural, } \\
\text { industrial }\end{array}$ \\
\hline \multirow[t]{2}{*}{$\begin{array}{c}\text { Distance } \\
\text { from AMD, } \\
\mathrm{km}\end{array}$} & \multicolumn{2}{|l|}{110} & 0 & 52 & 31 & 180 & & \\
\hline & Range & Mean & \multicolumn{6}{|c|}{ Mean } \\
\hline $\mathrm{Li}$ & $25.85-110.30$ & 56.34 & 38.80 & & 57.6 & & 47.1 & - \\
\hline V & $72.60-117.70$ & 92.25 & - & & 130.45 & 103 & 73.5 & 109.25 \\
\hline $\mathrm{Cr}$ & $77.96-101.50$ & 84.94 & 2042.31 & & 90.7 & 49.9 & 61.5 & 133.5 \\
\hline Co & $27.45-75.44$ & 43.35 & 20.34 & & 34.4 & 9.6 & 7.7 & 3.0 \\
\hline $\mathrm{Ni}$ & $41.82-82.74$ & 57.17 & 42.79 & & 35.0 & 15 & 33.1 & 110.25 \\
\hline $\mathrm{Cu}$ & $44.83-78.10$ & 60.01 & 37.12 & 236 & 1106.2 & 310 & 36.8 & 29.6 \\
\hline $\mathrm{Zn}$ & $62.88-207.76$ & 121.40 & 43.20 & 422 & 3330.4 & 118 & 85.6 & 79.23 \\
\hline As & $5.36-10.86$ & 7.15 & 2.99 & 43.6 & 408.3 & 44 & 15.2 & 6.13 \\
\hline $\mathrm{Se}$ & $0.05-0.19$ & 0.10 & 0.71 & & 1.85 & & - & \\
\hline $\mathrm{Rb}$ & $4.36-7.30$ & 5.87 & 1.67 & & & 80 & - & \\
\hline $\mathrm{Sr}$ & $65.68-103.30$ & 82.21 & 49.40 & & 62.55 & 290 & 172 & \\
\hline $\mathrm{Nb}$ & $6.39-14.86$ & 9.36 & 8.26 & & & & 63.5 & \\
\hline $\mathrm{Cd}$ & $0.02-0.70$ & 0.47 & 0.91 & 2.34 & 2.8 & 1.2 & 0.1 & \\
\hline $\mathrm{Ba}$ & $157.32-201.76$ & 176.36 & 108.25 & & 271.15 & 434 & & \\
\hline Sn & $1.05-2.15$ & 1.55 & 1.35 & & & & 4.5 & \\
\hline $\mathrm{Sb}$ & $0.67-1.00$ & 0.77 & - & & & 1.1 & 1.4 & \\
\hline $\mathrm{Hg}$ & $0.40-3.52$ & 1.48 & 2.35 & & & & 0.045 & \\
\hline $\mathrm{Pb}$ & $11.35-30.17$ & 17.46 & 77.24 & 115 & 64.8 & 17 & 55.2 & 16.78 \\
\hline Th & $0.81-1.28$ & 1.07 & 1.06 & & 5.05 & & - & \\
\hline$U$ & $1.68-4.61$ & 2.84 & 3.69 & & 6.45 & 3.5 & 4.0 & \\
\hline References & \multicolumn{3}{|c|}{ This study } & $\begin{array}{l}\text { Luo et al., } \\
\quad 2020\end{array}$ & $\begin{array}{l}\text { Lecomte et } \\
\text { al., } 2016\end{array}$ & $\begin{array}{c}\text { Borrego et } \\
\text { al., } 2012\end{array}$ & $\begin{array}{c}\text { Koukina et al., } \\
2021\end{array}$ & $\begin{array}{l}\text { Allafta and } \\
\text { Opp, } 2020\end{array}$ \\
\hline
\end{tabular}


elements in sediments of other river mouths in the world. We have divided the trace elements into four categories: alkali and alkaline earth metals ( $\mathrm{Li}, \mathrm{Rb}, \mathrm{Sr}, \mathrm{Ba}$ ), transition metals ( $\mathrm{V}, \mathrm{Cr}, \mathrm{Co}, \mathrm{Ni}$, $\mathrm{Cu}, \mathrm{Zn}, \mathrm{Nb}, \mathrm{Cd}, \mathrm{Hg}$ ), other metals and nonmetals ( $\mathrm{Sn}, \mathrm{Sb}, \mathrm{Pb}, \mathrm{As}, \mathrm{Se}$ ), and actinide (Th, U).

\section{Alkali and alkaline earth metals}

Among the analysed trace elements, Ba $(176.36 \mathrm{mg} / \mathrm{kg})$ had the highest average content in the Kosva Bay sediments with a range of 157.32$201.76 \mathrm{mg} / \mathrm{kg}$. At the same time, according to UCC-normalized data, insignificant Li enrichment (by 1-5 times) was observed in the bay sediments; the content of other elements was significantly lower than the UCC values (Figure 4). In general, in the bay sediments, the content of $\mathrm{Li}, \mathrm{Rb}, \mathrm{Sr}$, and Ba was 1.5-3.5 times higher than in the place of acid mine waters discharge. The content of alkali and alkaline earth metals in the bay sediments was low for all elements relative to sediments of river mouths in other regions of the world (Table 3), with the exception of $\mathrm{Sr}$, the content of which was higher than that of the sediments in the Amarillo River mouth (Argentina), influenced by AMD from high-sulphidation epithermal deposits.

\section{Transition metals}

$\mathrm{Zn}$ showed high concentrations among transition metals in the analysed bay sediments (62.88$207.76 \mathrm{mg} / \mathrm{kg}$ ) with an average value of 121.40 $\mathrm{mg} / \mathrm{kg}$. The lowest concentrations were found for $\mathrm{Cd}$ with an average concentration of $0.47 \mathrm{mg} / \mathrm{kg}$. Transition metals formed the following row in decreasing order of average concentration values: $\mathrm{Zn}>\mathrm{V}>\mathrm{Cr}>\mathrm{Cu}>\mathrm{Ni}>\mathrm{Co}>\mathrm{Nb}>\mathrm{Hg}>\mathrm{Cd}$. Figure 4 shows a graph of the composition of UCC-normalized samples taken from the Kosva Bay. The $\mathrm{Hg}$ content in the bay sediments was 8-70 times higher than the average UCC value. Significant elevation (by 5-7 times) was also noted for $\mathrm{Cd}$ content. This indicates the enrichment of the bay sediments with the mentioned elements. The content of $\mathrm{Co}, \mathrm{Cu}$, and $\mathrm{Zn}$ was higher relative to the UCC values, and the content of the remaining elements fell within the range of UCC values. Concentration comparison of bottom sediments of the bay with sediments in the place of acid mine water discharge showed significant decrease (by more than 24 times) in the content of $\mathrm{Cr}$, while slight elevation in the content of $\mathrm{Zn}, \mathrm{Co}, \mathrm{Cu}$, and $\mathrm{Ni}$ was found. The content of transition metals in the bay sediments was significantly lower than that in the sediments of the Hengshi River mouth (China) polluted by AMD from polymetallic mine. At the same time, comparing the results obtained for the Kosva Bay to the Amarillo River (Argentina) sediments, affected by AMD from high-sulphidation epithermal deposits, we should note higher $\mathrm{Co}$ and $\mathrm{Ni}$ concentrations in the sediments of the studied bay. These concentrations, in combination with $\mathrm{Cr}$ and $\mathrm{Zn}$, exceeded the values for sediments in the Tinto River mouth (Spain) and the Cai River mouth (Vietnam).

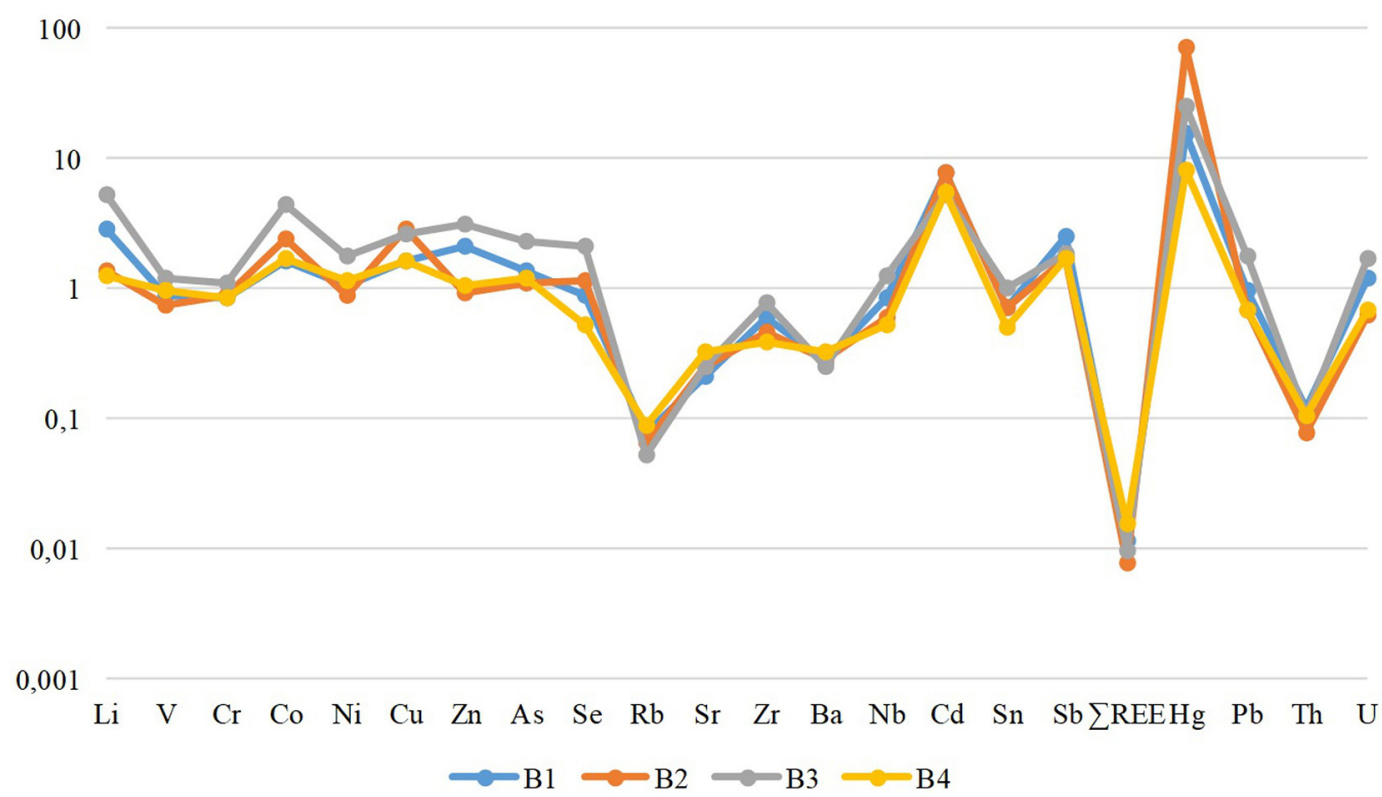

Figure 4. REE concentrations in sediments of the Kosva Bay normalized to the UCC values [Rudnick and Gao, 2003] 


\section{Other metals and nonmetals}

Among all the studied trace elements, the Se content in the bay sediments was the lowest $(0.05-0.19 \mathrm{mg} / \mathrm{kg})$ with an average value of 0.10 $\mathrm{mg} / \mathrm{kg}$. In all sampling points, Sb and As content was elevated relative to the average UCC values. Only in two sampling points (B2 and B3), an excess in Se content was found, and only in $\mathrm{B} 3$ there was a slight excess in $\mathrm{Sn}$ and $\mathrm{Pb}$ content relative to the average UCC values. In general, in the bay sediments, the content of $\mathrm{Sn}, \mathrm{Pb}, \mathrm{As}$, and Se was lower than in the area of acid mine water discharge. The content of other metals and nonmetals in the bay sediments showed low values only for $\mathrm{Sn}, \mathrm{Sb}$, and Se content relative to other sediments in the river mouth exposed to various pollution sources. The content of $\mathrm{Pb}$ in sediments of the Kosva Bay was close to that of the Tinto River (Spain); the content of $\mathrm{Pb}$ and As was close to that of the Shatt Al-Arab River (Iraq).

\section{Actinide}

The average concentration of $\mathrm{Th}$ and $\mathrm{U}$ in the Kosva Bay sediments reached 1.07 and 2.84 $\mathrm{mg} / \mathrm{kg}$, respectively. The content of Th in the bay sediments was at the level of concentrations noted in the area of acid mine water discharge, while the content of $U$ was slightly lower. Th content in the bay sediments, compared to the average UCC concentrations, was significantly lower. At the same time, the $U$ content in some points of the bay (B1 and B3) was higher than the UCC value. Compared to the studies for other territories (Table 3), the contents of Th and U in the Kosva Bay sediments showed low values.

\section{Rare earth elements}

The content of REE in the samples of bottom sediments of the Kosva Bay varied (Table 4). Thus, the highest values were noted for Ce content, while the Tm concentrations were the lowest. Total REE ( $\mathrm{REE}$ ) concentrations ranged from 66.8 to $83.6 \mathrm{mg} / \mathrm{kg}$ and were represented by the following descending series: $\mathrm{Ce}>\mathrm{Nd}>$ $\mathrm{La}>\mathrm{Gd}>\mathrm{Dy}>\mathrm{Sm}>\mathrm{Pr}>\mathrm{Yb}>\mathrm{Er}>\mathrm{Eu}>\mathrm{Ho}>\mathrm{Tb}>$ $\mathrm{Lu}>\mathrm{Tm}$. All rare earth elements in the bay sediments were significantly depleted relative to the UCC values. In the bay sediments, an increase in LREE concentrations was noted relative to sediments in the AMD zone. In the bay sediments,

Table 4. Concentrations of trace elements and REE in sediments of the Kosva Bay and comparison of the average REE concentrations in other sediments in river mouths $(\mathrm{mg} / \mathrm{kg})$

\begin{tabular}{|c|c|c|c|c|c|c|c|}
\hline Component & Max & Min & Average & $\begin{array}{l}\text { Sediment in } \\
\text { AMD zone }\end{array}$ & Volga, Russia & $\begin{array}{c}\text { Zrmanja, } \\
\text { Croatia }\end{array}$ & $\begin{array}{l}\text { Tinto, } \\
\text { Spain }\end{array}$ \\
\hline La & 2.45 & 1.32 & 2.05 & 0.74 & 31.76 & 16.03 & 10.40 \\
\hline $\mathrm{Ce}$ & 5.56 & 3.10 & 4.67 & 3.30 & 65.33 & 31.39 & 23.36 \\
\hline $\mathrm{Pr}$ & 0.73 & 0.40 & 0.61 & 0.34 & 7.43 & 3.89 & 4.11 \\
\hline $\mathrm{Nd}$ & 3.12 & 1.58 & 2.52 & 1.80 & 28.26 & 17.47 & 18.42 \\
\hline $\mathrm{Sm}$ & 0.74 & 0.37 & 0.57 & 0.54 & 5.60 & 3.19 & 4.83 \\
\hline $\mathrm{Eu}$ & 0.24 & 0.14 & 0.18 & 0.10 & 1.27 & 0.66 & 1.10 \\
\hline Gd & 0.82 & 0.43 & 0.63 & 0.61 & 4.80 & 2.54 & 4.88 \\
\hline $\mathrm{Tb}$ & 0.08 & 0.04 & 0.05 & 0.05 & 0.70 & 0.42 & 0.79 \\
\hline Dy & 0.74 & 0.35 & 0.51 & 0.79 & 4.13 & 2.12 & 4.41 \\
\hline Ho & 0.14 & 0.06 & 0.09 & 0.12 & 0.87 & 0.41 & 1.02 \\
\hline Er & 0.49 & 0.23 & 0.33 & 0.49 & 2.43 & 1.12 & 2.63 \\
\hline $\mathrm{Tm}$ & 0.05 & 0.01 & 0.02 & 0.02 & 0.30 & 0.15 & 0.43 \\
\hline $\mathrm{Yb}$ & 0.53 & 0.30 & 0.37 & 0.50 & 1.30 & 0.98 & 2.81 \\
\hline Lu & 0.07 & 0.03 & 0.04 & 0.02 & 0.37 & 0.14 & 0.46 \\
\hline$\sum$ REE & 108.50 & 66.78 & 83.56 & & & & 79.64 \\
\hline LREE & 13.65 & 7.34 & 11.24 & & & & \\
\hline HREE & 94.85 & 59.45 & 72.33 & & & & \\
\hline LREE/HREE & 0.14 & 0.12 & 0.16 & & & & \\
\hline \multicolumn{5}{|c|}{ This study } & $\begin{array}{c}\text { Maslov and } \\
\text { Shevchenko, } \\
2019\end{array}$ & $\begin{array}{c}\text { Fiket et al., } \\
2017\end{array}$ & $\begin{array}{l}\text { López- } \\
\text { González et } \\
\text { al., } 2012\end{array}$ \\
\hline
\end{tabular}


significantly low concentrations of REE were noted relative to the studied sediments of the Volga River mouth, Zrmanja River mouth (Croatia) and Tinto River mouth (Spain).

\section{Trace elements enrichment and risk assessment}

The use of the average UCC values as normalization factor for the EF and Igeo indices for assessing the pollution level allowed for a better approach to analysing anthropogenically induced enrichment levels [Borrego et al., 2004]. The highest enrichment was noted for $\mathrm{Hg}$ content in sampling points B2 and B3 (134 and 33, respectively) (Figure 5). The enrichment factor (EF) lower than 2, taking into account the average value in all sampling points, was noted for $\mathrm{Pb}$, $\mathrm{V}, \mathrm{Cr}, \mathrm{Nb}, \mathrm{Sn}, \mathrm{Ba}, \mathrm{Sr}, \mathrm{Rb}, \mathrm{Th}$, and all REE content, which indicated the deficiency to minimal enrichment category of pollution and the entry of these elements into sediments entirely from natural weathering processes [Li, 2019]. As shown in Figure 5, according to the EF index, taking into account the average values for sampling points B1-B4 in the Kosva Bay, contents of U, Ni, Se, $\mathrm{As}, \mathrm{Zn}, \mathrm{Sb}, \mathrm{Cu}$, and Co corresponded to the moderate enrichment category, and only the contents

1000

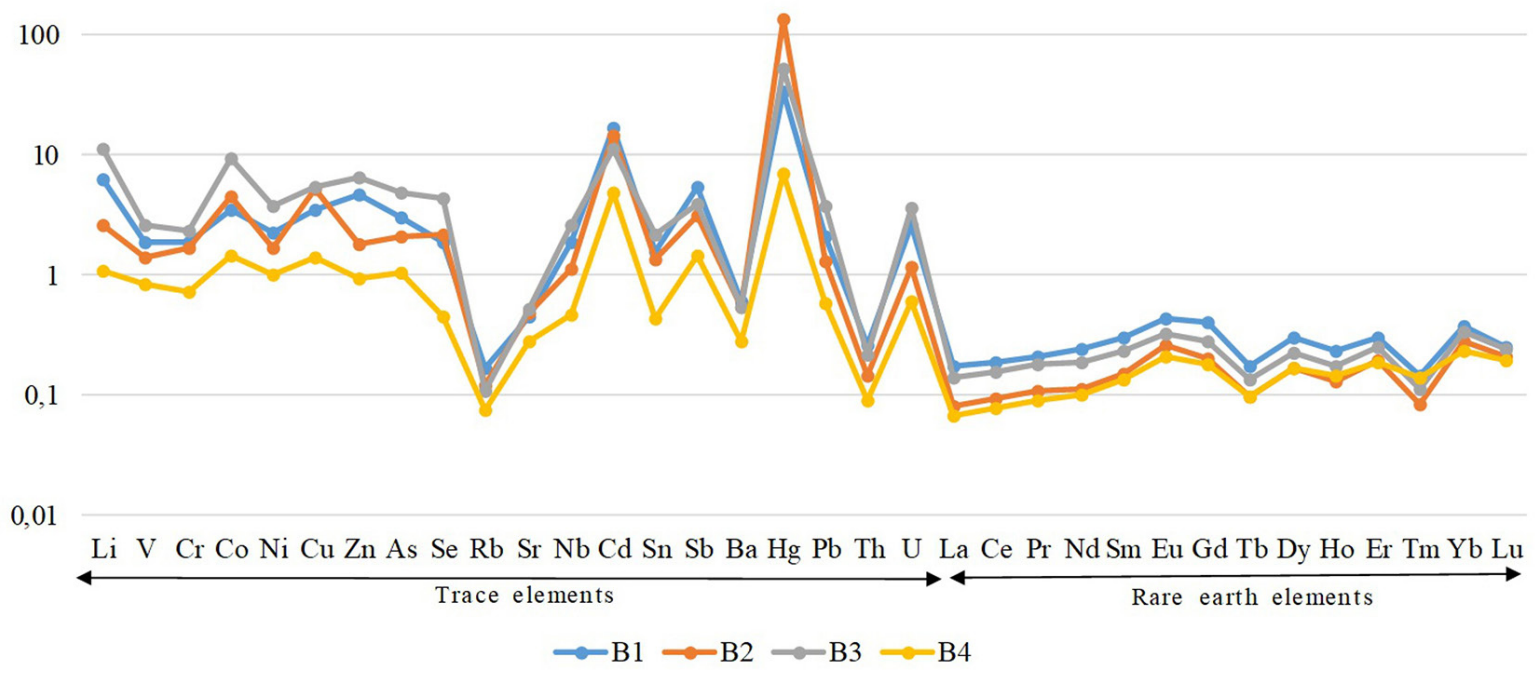

Figure 5. EF values of trace elements and rare earth elements in bay sediments at 4 sites

15

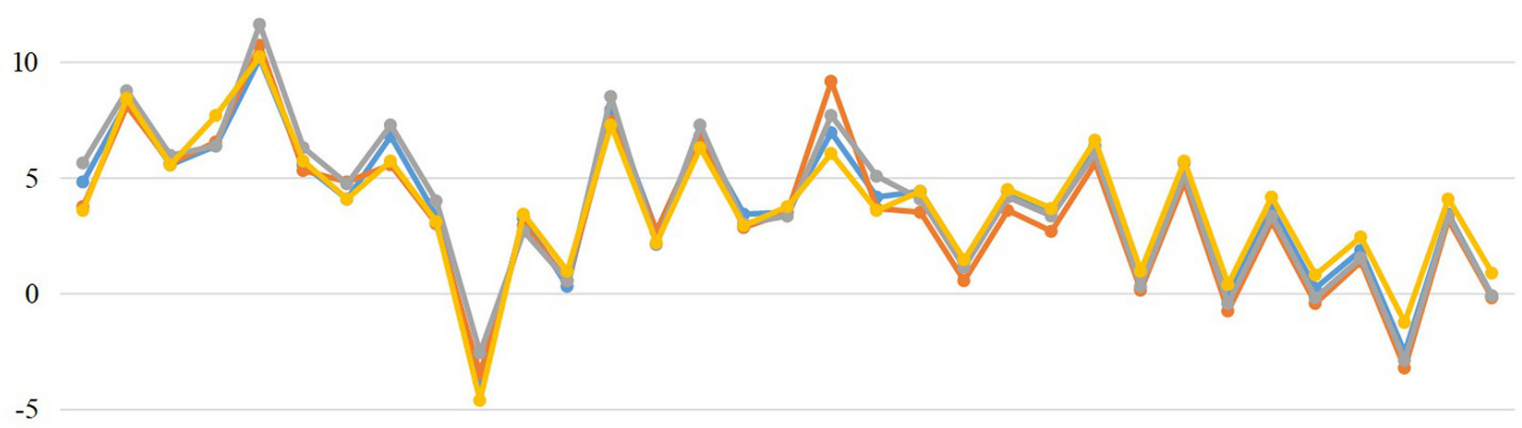

$-10$

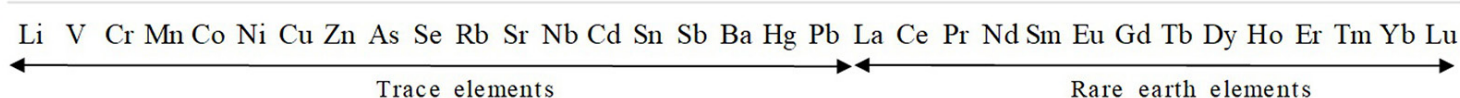

$\multimap \mathrm{B} 1 \multimap \mathrm{B} 2 \multimap \mathrm{B} 3 \multimap \mathrm{B} 4$

Figure 6. Igeo values of trace elements and rare earth elements in bay sediments at 4 sites 
of $\mathrm{Li}$ and $\mathrm{Cd}$ corresponded to the significant enrichment category.

To assess the state of pollution, the geoaccumulation index (Igeo) of the studied elements at each sampling site was calculated, which is shown in Figure 6. Igeo $<0$ indicated the absence of Se and Tm contamination in all sampling points. In general, taking into account the average value of Igeo, the most severe pollution was the $\mathrm{Co}, \mathrm{V}, \mathrm{Nb}, \mathrm{Hg}, \mathrm{Sn}, \mathrm{Zn}, \mathrm{Sm}, \mathrm{Ni}$, $\mathrm{Cr}$, and $\mathrm{Gd}$ pollution which corresponded to extremely contaminated category (Igeo $>5$ ). In all sampling points, the Co contamination was the highest; Igeo values varied from 10.1 to 11.6. Cobalt was the indicator of acid mine water discharge, since high content of this element was noted in acid mine waters, reaching 0.17 $\mathrm{mg} / \mathrm{L}$ on average [Fetisova, 2021].

The potential ecological risk index (RI) of trace elements and rare earth elements in sediments of the Kosva Bay is presented in Figure 7. According to the data obtained, the values of trace elements content, including rare earth elements, ranged from 192 to 320 , which corresponded to the pollution categories from moderate risk to considerable risk. At the same time, the highest level of contamination with a considerable risk was found at the sampling point B3. With reference to the average value of the potential ecological risk factor, the studied trace elements and rare earth elements formed the following series: $U>$ As $>\mathrm{Cd}>\mathrm{Cu}>\mathrm{Lu}>\mathrm{Ni}>\mathrm{Sr}>\mathrm{Hg}>\mathrm{Pb}>\mathrm{Tm}>\mathrm{Zn}>$ $\mathrm{Eu}>\mathrm{Ho}>\mathrm{Yb}>\mathrm{Cr}>\mathrm{Tb}>\mathrm{Er}>\mathrm{Dy}>\mathrm{Gd}>\mathrm{Sm}>\mathrm{Pr}>$ $\mathrm{Co}>\mathrm{Ba}>\mathrm{Nd}>\mathrm{La}>\mathrm{Ce}$.

Concentrations of $\mathrm{Cr}, \mathrm{Ni}$, and $\mathrm{Hg}$ in the Kosva Bay were higher than the PEC level. One-time exceedances above the PEC level were noted for
$\mathrm{Cr}$ (up to 8 times excess; sample B4), $\mathrm{Ni}$ and $\mathrm{Hg}$ (up to 1.7 and up to 1.2 times excess, respectively; sample B3). The average PECQ of trace elements was $0.75(0.42-1.17)$ (Figure 7). It means that the total content of trace elements and rare earth elements in bottom sediments of the Kosva Bay exposes biological communities to moderate potential toxicity $(0.5<\mathrm{PECQ}<1.0)$. It should be noted that the heavy effect (PECQ $>1.0$ ) was found at sampling point B4, the farthest one from the confluence of the Kosva River.

\section{Ecotoxicological implications}

Different organisms can show different sensitivity to the content of trace elements and rare earth elements in bottom sediments. The result of chronic toxicity assessment of bottom sediments in the Kosva Bay for D. magna is shown in Figure 8. In the control group, the percentage of dead $D$. magna was less than $10 \%$ after the experiment, which indicated reliability and effectiveness of the test results. The survival rate of D. magna in the experimental group was $80 \%$ at the sampling point B1 and $93 \%$ in B4. The mortality rate in the experiment in relation to the control during the chronic experiment at the sampling point B1 was $17.2 \%$, in $\mathrm{B} 4-3.4 \%$.

One of the criteria for evaluating chronic toxicity is to determine significant deviation in the fertility of the test organisms under study in comparison with control. When comparing the average number of births of test organisms between sampling points during the experiment, the standard deviation of this indicator for B4 sediment samples indicated higher variability in the number of neonates (Figure 9).

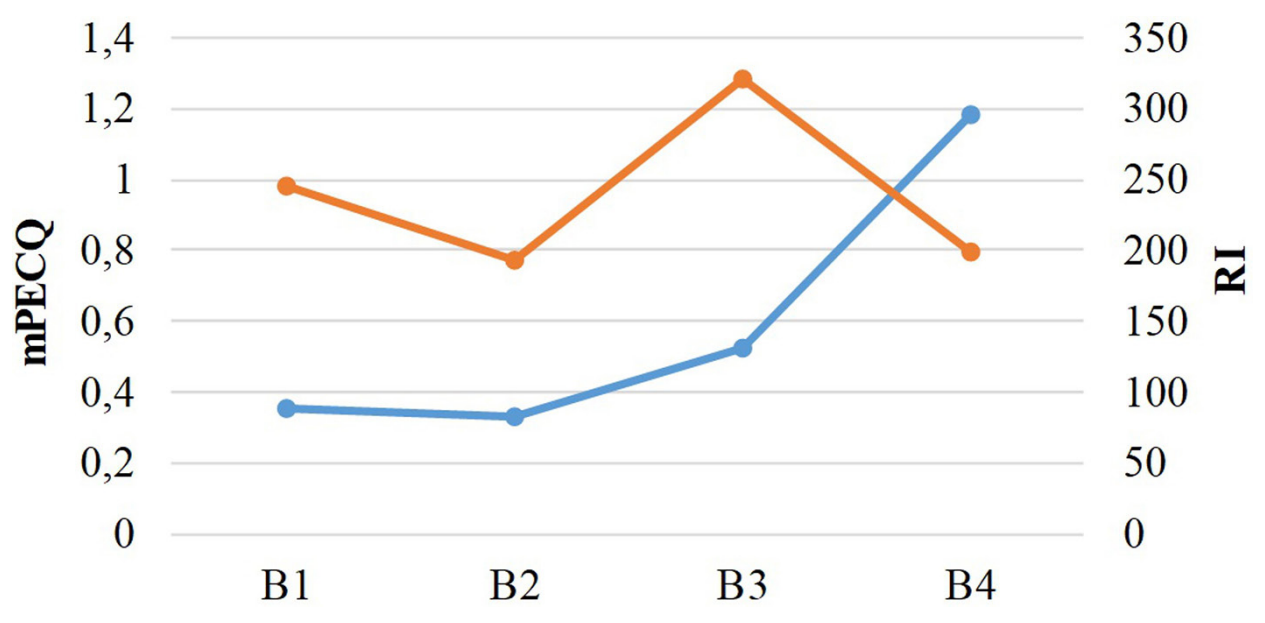

Figure 7. Mean PECQ (mPECQ) and potential ecological risk index (RI) of the bay sediments 


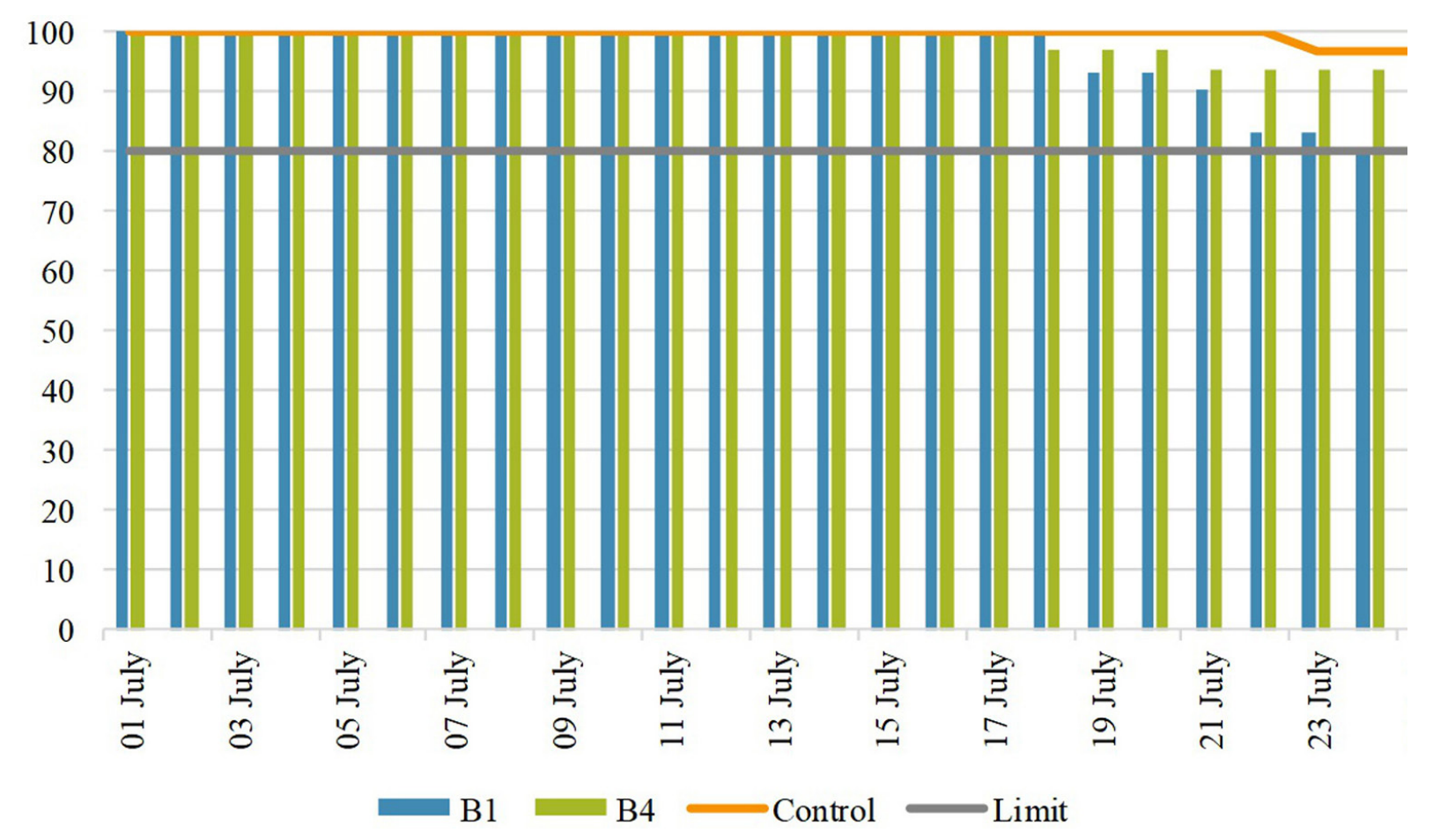

Figure 8. Comparison of survival rates of Daphnia magna exposed to the samples from the Kosva Bay bottom sediments to the control group during the whole test period

B1

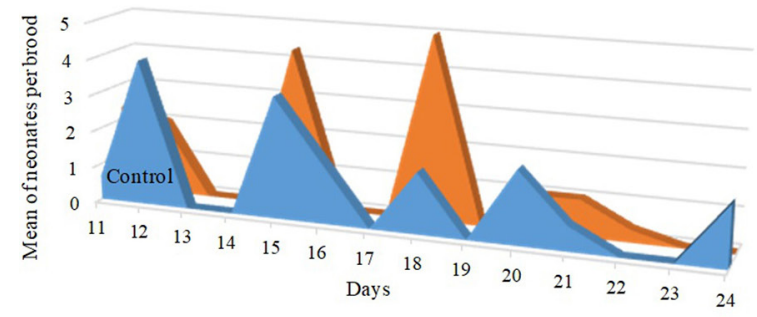

B4

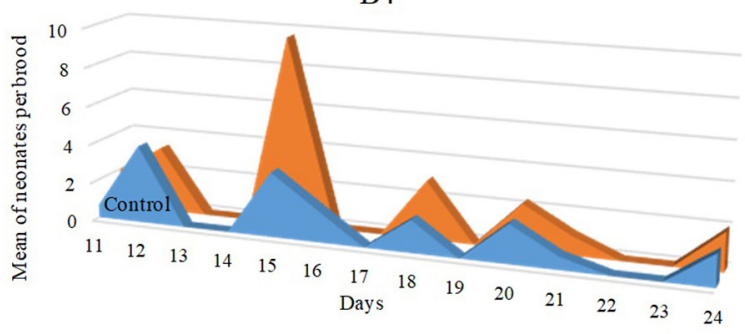

Figure 9. Number of neonates per D. magna brood exposed to sediment samples from the Kosva Bay Hatched juveniles appeared on 11th day of the experimen

The average number of juveniles per female in the control sample was 4.5 , and in the experimental samples B1 and B4 - 3.6 and 6.7, respectively. According to clause 9.2.3 FR.1.39.2007.03222, if $t d \leq t s t$, then the revealed differences in the fertility of daphnia in the tested sample and the control are unreliable and do not have a chronic effect. Thus, in samples B1 and $\mathrm{B} 4$, the reliability indicator of the difference between the two compared values and the value of the Student's criterion was determined as $-0.10 \leq 2.78$ and $-2.14 \leq 2.78$, respectively. Taking into account the percentage of dead daphnia, the average number of juveniles born per female and a significant deviation in the number of juveniles born per one surviving female, the water extract from bottom sediments in B1 and B4 did not have a chronic toxic effect on the test object Daphnia magna Straus at $100 \%$ (dilution ratio 1) and all subsequent concentrations.

Experiments with Scenedesmus showed the lack of stimulation of algal cell growth, since the decrease in the number of algal cells of Scenedesmus quadricauda Breb. was no more than $20 \%$ within 72 hours of the experiment (Table 5). Water extract from bottom sediments of the Kosva Bay at sampling points B1 and B4 had no toxic effect on the growth of algal cells at $100 \%$ dilution ratio and all subsequent concentrations.

The results of toxicity assessment of the Kosva Bay bottom sediments indicated no toxicity according to the PE classification (Percent toxic effect), since the PE value was less than $20 \%$ (class I - no acute toxicity). 
Table 5. Results of ecotoxicity assessment for the bay sediment samples using Scenedesmus quadricauda Breb

\begin{tabular}{|c|c|c|c|c|c|c|c|c|c|}
\hline \multirow[t]{2}{*}{ Sediment } & \multirow[t]{2}{*}{$\mathrm{pH}$} & \multirow[t]{2}{*}{ Salinity } & \multicolumn{2}{|c|}{$\begin{array}{l}\text { EC100, } \\
\text { the number of algae, } \\
\text { thousand cells/sm }{ }^{3}\end{array}$} & \multirow[t]{2}{*}{ I, \% } & \multicolumn{2}{|c|}{$\begin{array}{l}\mathrm{EC}_{50} \\
\text { the number of algae, } \\
\text { thousand cells/sm }{ }^{3}\end{array}$} & \multirow[t]{2}{*}{ I, \% } & \multirow[t]{2}{*}{ Toxicity } \\
\hline & & & Assay 1 & Assay 2 & & Assay 1 & Assay 2 & & \\
\hline B1 & $6.83 / 9.39^{*}$ & $0.179 / 0.246^{* *}$ & 26.75 & 626.25 & 2,57 & 29.88 & 631.25 & 1.79 & No acute toxicity \\
\hline B4 & $7.17 / 9.95$ & $0.198 / 0.264$ & 25.13 & 632.20 & 1,59 & 31.00 & 636.25 & 1.01 & No acute toxicity \\
\hline
\end{tabular}

$* \mathrm{pH}$ before the experiment/pH after the experiment; ** Salinity before the experiment/salinity after the experiment.

\section{CONCLUSIONS}

Trace element and rare earth element pollution of bottom sediments of the Kosva Bay were assessed using various instruments, methods, and indices. Mineral composition, grain size, sedimentation conditions and AMD in the middle part of the Kosva River drainage basin determined the distribution of trace elements and rare earth elements in bottom sediments of the Kosva Bay. Average concentrations of most trace elements of the studied bottom sediments were higher than the average concentrations of UCC, as opposed to rare earth elements which content was significantly lower. Despite the pollution of the bay sediments at the moderate enrichment level (according to EF), extremely contaminated level (according to Igeo), moderate risk to considerable risk level (according to RI), and moderate potential toxicity for biological communities (according to PESQ), the results of chronic and acute toxicity test on the test objects D. magna and Scenedesmus quadricauda Breb indicated no effect of the water extract from bottom sediments on the test objects. This result confirms the need of an integrated approach to the study of samples with a combination of chemical and ecotoxicological analyses. The noted higher category of pollution in terms of RI and mPECQ in remote points of the Kosva Bay (B3 and B4) sets the objective of further studies of trace elements and toxicity of bottom sediments in the water area of the Kama Reservoir in the impact zone of the Kosva River, primarily in even more remote areas of the old river bed.

\section{Acknowledgements}

The study was carried out with the financial support of the Russian Foundation for Basic Research within the framework of scientific project No. 19-05-50071 and the Ministry of Science and Higher Education, project No. 2019-0858.

\section{REFERENCES}

1. Adeel M., Lee J.Y., Zain M., Rizwan M., Nawab A., Ahmad M.A., Shafiq M., Yi H., Jilani G., Javed R., Horton R., Rui Y., Tsang D., Xing B. 2019. Cryptic footprints of rare earth elements on natural resources and living organisms. Environment international, 127, 785-800. https://doi.org/10.1016/j. envint.2019.03.022

2. Allafta H., Opp C. 2020. Spatio-temporal variability and pollution sources identification of the surface sediments of Shatt Al-Arab River, Southern Iraq. Scientific reports, 10(1), 6979. https://doi. org/10.1038/s41598-020-63893-w

3. Alvarenga P., Guerreiro N., Simões I., Imaginário M.J., Palma P. 2021. Assessment of the Environmental Impact of Acid Mine Drainage on Surface Water, Stream Sediments, and Macrophytes Using a Battery of Chemical and Ecotoxicological Indicators. Water, 13, 1436. https://doi.org/10.3390/w13101436

4. Balkis N., Aksu A., Okuş E., Apak R. 2010. Heavy metal concentrations in water, suspended matter, and sediment from Gökova Bay, Turkey. Environmental monitoring and assessment, 167(1-4), 359370. https://doi.org/10.1007/s10661-009-1055-x

5. Baran A., Tarnawski M., Koniarz T. 2016. Spatial distribution of trace elements and ecotoxicity of bottom sediments in Rybnik reservoir, Silesian-Poland. Environ Sci Pollut Res Int, 23(17), 17255-17268. https://doi.org/10.1007/s11356-016-6678-1

6. Boguta P., Skic K., Baran A., Szara-Bąk M. 2022. The influence of the physicochemical properties of sediment on the content and ecotoxicity of trace elements in bottom sediments. Chemosphere, 287(Pt 4), 132366. https://doi.org/10.1016/j. chemosphere.2021.132366

7. Borrego J., Carro B., López-González N., de la Rosa J., A. Grande J.A., Gómez T., De la Torre M.L. 2012. Effect of acid mine drainage on dissolved rare earth elements geochemistry along a fluvial-estuarine system: the Tinto-Odiel Estuary (S.W. Spain). Hydrology Research, 43(3), 262-274. https://doi. org/10.2166/nh.2012.012b

8. Borrego J., López-González N., Carro B. 2004. Geochemical signature as paleoenvironmental markers in Holocene sediments of the Tinto River estuary 
(Southwestern Spain) Estuarine. Coastal and Shelf Science, 61(4), 631-641. https://doi.org/10.1016/j. ecss.2004.07.004

9. Byrne P., Reid I., Wood P.J. 2013. Changes in macroinvertebrate community structure provide evidence of neutral mine drainage impacts. Environmental science. Processes \& impacts, 15(2), 393-404. https://doi.org/10.1039/c2em30447c

10. Chan W.S., Routh J., Luo C., Dario M., Miao Y., Luo D., Wei, L. 2021. Metal accumulations in aquatic organisms and health risks in an acid mineaffected site in South China. Environmental geochemistry and health, 43(11), 4415-4440. https:// doi.org/10.1007/s10653-021-00923-0

11. Chen H., Chen Z., Chen Z., Ou. X., Chen J. 2020. Calculation of Toxicity Coefficient of Potential Ecological Risk Assessment of Rare Earth Elements. Bull Environ Contam Toxicol, 104, 582-587. https://doi.org/10.1007/s00128-020-02840-x

12. Daesslé L.W., Lugo-Ibarr, K.C., Tobschall H.J., Melo M., Gutiérrez-Galindo E.A., García-Hernández J., Alvarez L.G. 2009. Accumulation of As, Pb, and $\mathrm{Cu}$ associated with the recent sedimentary processes in the Colorado delta, South of the United States-Mexico boundary. Archives of environmental contamination and toxicology, 56(4), 680-692. https://doi.org/10.1007/s00244-008-9218-2

13. Dauvalter V.A. 2012. Geoecology of lake sediments. Murmansk: Murmansk STU, 242. (in Russian)

14. Federal Register FR 1.39.2007.03222. 2007. Methodology for determining the toxicity of water and water extracts from soils, sewage sludge, and waste by mortality and changes in fertility of daphnias. Moscow: Akvaros, 51.

15. Federal Register FR 1.39.2007.03223.2007 Methodology for determining the toxicity of water and aqueous extracts from soils, sewage sludge, waste by mortality and changes in chlorophyll fluorescence levels and algae cell numbers. Moscow: Akvaros, 48.

16. Fetisova N.F. 2021.Study of migration forms of metals in rivers affected by acid mine drainage of the Kizel coal basin. Bulletin of the Tomsk Polytechnic University. Geo Assets Engineering, 332(1), 141-152. https:// doi.org/10.18799/24131830/2021/1/3007

17. Fiket Z., Mikac N., Kniewald G. 2017. Influence of the geological setting on the REE geochemistry of estuarine sediments: A case study of the Zrmanja River estuary (eastern Adriatic coast). Journal of Geochemical Exploration, 182(PtA), 70-79. https:// doi.org/10.1016/j.gexplo.2017.09.001

18. Fonseca R., Pinho C., Albuquerque T., Araújo J. 2021. Environmental Factors and Metal Mobilisation in Alluvial Sediments-Minas Gerais, Brazil. Geosciences, 11(3), 110. https://doi.org/10.3390/ geosciences 11030110
19. Gala'n E., Go'mez-Ariza J.L., Gonza'lez I., Ferna'ndez-Caliani J.C., Morales E., Gira'ldez I. 2003. Heavy metal partitioning in river sediments severely polluted by acid mine drainage in the Iberian Pyrite Belt. Applied Geochemistry, 18, 409-421.

20. Galhardi J.A., Bonotto D.M. 2016. Hydrogeochemical features of surface water and groundwater contaminated with acid mine drainage (AMD) in coal mining areas: a case study in southern Brazil. Environ Sci Pollut Res, 23, 18911-18927. https://doi. org/10.1007/s11356-016-7077-3

21. Gorgulenko V.V., Yanygina L.V. 2014. Ecotoxicological assessment of water and bottom sediments Novosibirsk reservoir. Water resources, 41(3), 284 292. https://doi.org/10.1134/S0097807814030063

22. Hakanson L. 1980. An ecological risk index for aquatic pollution control.a sedimentological approach. Water Research, 14(8), 975-1001.

23. Iqbal J., Shah M.H. 2015. Study of Selected Metals Distribution, Source Apportionment, and Risk Assessment in Suburban Soil, Pakistan. Journal of Chemistry, 2015(2-3), 1-8. http://dx.doi. org/10.1155/2015/481324

24. Jung H.B., Yun S.T., Mayer B., Kim S.O., Park S.S., Lee P.K. 2005. Transport and sediment-water partitioning of trace metals in acid mine drainage: An example from the abandoned Kwangyang Au-Ag mine area, South Korea. Environmental Geology, 48(4-5), 437-449. https://doi.org/10.1007/s00254-005-1257-7

25. Koukina S.E., Lobus N.V., Shatravin A.V. 2021. Dataset on the abundance, enrichment and partitioning of chemical elements between the filtered, particulate and sedimentary phases in the Cai River estuary (South China Sea). Data in brief, 38, 107412. https:// doi.org/10.1016/j.dib.2021.107412

26. Kulbat E., Sokołowska A. 2019. Methods of assessment of metal contamination in bottom sediments (Case study: Straszyn Lake, Poland). Archives of Environmental Contamination and Toxicology, 77, 605618. https://doi.org/10.1007/s00244-019-00662-5

27. Kublitskiy Y., Kulkova M., Druzhinina O., Subetto D., Stančikaitè M., Gedminienè L., Arslanov K. 2020. Geochemical Approach to the Reconstruction of Sedimentation Processes in Kamyshovoye Lake (SE Baltic, Russia) during the Late Glacial and Holocene. Minerals, 10, 764. https://doi.org/10.3390/min 10090764

28. Krasilnikova S.A., Blinov S.M. 2017. Effects of acid mine water discharge in the Kizel coal basin. Natural and Technical Sciences, 11(113)C, 153-154.

29. Lecomte K.L., Maza S.N., Collo1 G., Sarmiento A.M., Depetris P.J. 2017. Geochemical behavior of an acid drainage system: the case of the Amarillo River, Famatina (La Rioja, Argentina). Environ Sci Pollut Res, 24, 1630-1647. https://doi.org/10.1007/ s11356-016-7940-2 
30. Lee S.H., Kim I., Kim K.W., Lee B.T. 2015. Ecological assessment of coal mine and metal mine drainage in South Korea using Daphnia magna bioassay. Springer Plus, 4, 518. https://doi.org/10.1186/ s40064-015-1311-1

31. Li H., Yang J., Ye B., Jiang D. 2019. Pollution characteristics and ecological risk assessment of 11 unheeded metals in sediments of the Chinese Xiangjiang River. Environmental geochemistry and health, 41(3), 1459-1472. https://doi.org/10.1007/ s10653-018-0230-9

32. Lin C., He M., Liu X., Guo W., Liu S. 2013. Distribution and contamination assessment of toxic trace elements in sediment of the Daliao River System, China Environ Earth Sci, 70, 3163-3173. DOI 10.1007/s12665-013-2382-3

33. López-González N., Borrego J., Carro B., Grande J. A., De la Torre M. L., Valente T. 2012. Rareearth-element fractionation patterns in estuarine sediments as a consequence of acid mine drainage: A case study in SW Spain. Boletín Geológico y Minero, 123(1), 55-64.

34. Luo C., Routh J., Dario M., Sarkar S., Wei L., Luo D., Liu, Y. 2020. Distribution and mobilization of heavy metals at an acid mine drainage affected region in South China, a post-remediation study. The Science of the total environment, 724, 138122. https://doi.org/10.1016/j.scitotenv.2020.138122

35. Macdonald D.D., Ingersoll C.G., Berger T.A. 2000. Development and evaluation of consensus-based sediment quality guidelines for freshwater ecosystems. Arch. Environ. Contam. Toxicol. 39, 20-31. https://doi.org/10.1007/s002440010075

36. Martínez-López S., Martínez-Sánchez M.J., PérezSirvent C. 2021. Do Old Mining Areas Represent an Environmental Problem and Health Risk? A Critical Discussion through a Particular Case. Minerals, 11, 594. https://doi.org/10.3390/min 11060594

37. Maslov A.V., Shevchenko V.P. 2019. REE-Th systematics of the suspended particulate matter and bottom sediments from the mouth zones of the world rivers of different categories/classes and some large Russian arctic rivers. Geokhimiya, 64(1), 59-78. https://doi.org/10.31857/S0016-752564159-78

38. Menshikova E., Osovetsky B., Blinov S., Belkin P. 2020. Mineral Formation under the Influence of Mine Waters (The Kizel Coal Basin, Russia). Minerals, 10(4), 364. https://doi.org/10.3390/min10040364

39. Mohammad Ali B.N., Lin C.Y., Cleophas F., Abdullah M.H., Musta B. 2015. Assessment of heavy metals contamination in Mamut river sediments using sediment quality guidelines and geochemical indices. Environ Monit Assess, 187(1), 4190. https:// doi.org/10.1007/s10661-014-4190-y

40. Muneera J., Al Obaidb A., Ullaha R., Rehman K.U., Erinled K.O. 2022. Appraisal of toxic metals in water, bottom sediments and fish of freshwater lake. Journal of King Saud University - Science, 34(1), 101685. https://doi.org/10.1016/j.jksus.2021.101685

41. Müller G. 1969. Index of geoaccumulation in sediments of the Rhine River. GeoJournal, 2(3), 108-118.

42. Nieto J.M., Sarmiento A.M., Olías M., Canovas C.R., Riba I., Kalman J., Delvalls T.A. 2007. Acid mine drainage pollution in the Tinto and Odiel rivers (Iberian Pyrite Belt, SW Spain) and bioavailability of the transported metals to the Huelva Estuary. Environment international, 33(4), 445-455. https://doi. org/10.1016/j.envint.2006.11.010

43. Nkansah M.A., Darko G., Dodd M., Opoku F., Essuman T.B., Antwi-Boasiako J. 2017. Assessment of pollution levels, potential ecological risk and human health risk of heavy metals/metalloids in dust around fuel filling stations from the Kumasi Metropolis, Ghana. Cogent Environmental Science, 3(1), 1412153. DOI: 10.1080/23311843.2017.1412153

44. Opekunov A.Yu., Janson S.Yu., Opekunova M.G., Kukushkin S.Yu. 2021. Mineral phases of metals in industrial sediments of St. Petersburg rivers with extreme pollution. Vestnik of Saint Petersburg University. Earth Sciences, 66(2). 267-288. https://doi. org/10.21638/spbu07.2021.205 (in Russian)

45. Opekunov A.Yu., Mitrofanova E.S., Spassky V.V., Opekunova M.G, Sheinerman N.A, Chernyshova A.V. 2020. Chemical composition and toxicity of bottom sediments of small streams of St. Petersburg. Water Resources, 47(2), 196-207. https://doi. org/10.31857/S032105962002011X.

46. Persoone G., Marsalek B., Blinova I., Törökne A., Zarina D., Manusadzianas L., Nalecz-Jawecki G., Tofan L., Stepanova N., Tothova L., Kolar B. 2003. A practical and user-friendly toxicity classification system with microbiotests for natural waters and wastewaters. Environmental toxicology, 18(6), 395-402. https://doi.org/10.1002/tox.10141

47. Pyankov S.V., Maximovich N.G., Khayrulina E.A. Berezina O.A., Shikhov A.N., Abdullin R.K. 2021. Monitoring Acid Mine Drainage's Effects on Surface Water in the Kizel Coal Basin with Sentinel-2 Satellite Images. Mine Water Environ, 40, 606-621. https://doi.org/10.1007/s10230-021-00761-7

48. Ren J., Liu Y., Wang F., He G., Deng X., Wei Z., Yao H. 2021. Mechanism and Influencing Factors of REY Enrichment in Deep-Sea Sediments. Minerals, 11, 196. https://doi.org/10.3390/min11020196

49. Report "On the state and environmental protection of the Perm Territory in 2020", available at: http:// www.permecology.ru

50. Rudnick R.L., Gao S. 2003. Composition of the Continental Crust. Treatise on Geochemistry,3, 1-64. https://doi.org/10.1016/B0-08-043751-6/03016-4

51. Sakan S.M., Djordjevic D.S., Manojlovic D.D., Polic P.S. 2009. Assessment of heavy metal pollutants 
accumulation in the Tisza river sediments. J Environ Manage, 90, 3382-3390. https://doi.org/10.1016/j. jenvman.2009.05.013

52. Skorbiłowicz M., Skorbiłowicz E., Górska M. 2018. The Content of Heavy Metals in Bottom Sediments of Selected Rivers of the Podlasie Province as an Impact Assessment of the Towns they are Adjacent with. J. Ecol. Eng., 19(4), 197-206. https://doi. org/10.12911/22998993/89650

53. Sojka M., Jaskuła J., Siepak M. 2019. Heavy Metals in Bottom Sediments of Reservoirs in the Lowland Area of Western Poland: Concentrations, Distribution, Sources and Ecological Risk. Water, 11(1), 56. https://doi.org/10.3390/w11010056

54. Soltani N., Moore F., Keshavarzi B., Sharifi R. 2014. Geochemistry of trace metals and rare earth elements in stream water, stream sediments and acid mine drainage from Darrehzar Copper Mine, Kerman, Iran. Water Qual. Expo. Health, 6, 97-114. https://doi.org/10.1007/s12403-014-0114-x

55. Szara M., Baran A., Klimkowicz-Pawlas A., Tarnawski M. 2020. Ecotoxicological characteristics and ecological risk assessment of trace elements in the bottom sediments of the Rożnów reservoir (Poland). Ecotoxicology (London, England), 29(1), 4557. https://doi.org/10.1007/s10646-019-02137-8

56. Terra N.R., Feiden I.R., Lucheta F., Gonçalves S.P., Gularte J.S. 2010. Bioassay using Daphnia magna Straus, 1820 to evaluate the sediment of Caí River (Rio Grande do Sul, Brazil). Acta Limnologica Brasiliensia, 22(4), 442-454. https://doi. org/10.4322/actalb.2011.008

57. Thisani S.K., Kallon D.V.V., Byrne P. 2020. Geochemical Classification of Global Mine Water Drainage. Sustainability, 12, 10244. https://doi. org/10.3390/su122410244
58. Torre B.M., Borrero-Santiago A.R., Fabbri E., Guerra R. 2019. Trace metal levels and toxicity in the Huelva Estuary (Spain): A case study with comparisons to historical levels from the past decades. Environmental Chemistry and Ecotoxicology, 1, 12-18. https://doi.org/10.1016/j.enceco.2019.07.002

59. Wang Z., Xu Y., Zhang Z., Zhang Y. 2021. Review: Acid Mine Drainage (AMD) in Abandoned Coal Mines of Shanxi, China. Water, 13, 8. https://dx.doi. org/10.3390/w13010008

60. Worakhunpiset S. 2018. Trace Elements in Marine Sediment and Organisms in the Gulf of Thailand. Int J Environ Res Public Health, 15(4), 810. https:// doi.org/10.3390/ijerph15040810

61. Wright I.A., Paciuszkiewicz K., Belmer N. 2018. Increased water pollution after closure of Australia's longest operating underground coal mine: a 13-month study of mine drainage, water chemistry and river ecology. Water, Air And Soil Pollution, 229, 55. https://doi.org/10.1007/ s11270-018-3718-0

62. Yi L., Gao B., Liu H., Zhang Y., Du C., Li Y. 2020. Characteristics and Assessment of Toxic Metal Contamination in Surface Water and Sediments Near a Uranium Mining Area. International Journal of Environmental Research and Public Health, 17(2), 548. https://doi.org/10.3390/ijerph17020548

63. Younger P.L. 2001. Mine water pollution in Scotland: nature, extent and preventative strategies. Science of The Total Environment, 265(1-3), 309-326. https://doi.org/10.1016/S0048-9697(00)00673-2

64. Zhang C., Yu Z.G., Zeng G.M., Jiang M., Yang Z.Z., Cui F., Zhu M.Y., Shen L.Q., Hu L. 2014. Effects of sediment geochemical properties on heavy metal bioavailability. Environment international, 73, 270281. https://doi.org/10.1016/j.envint.2014.08.010 